kirkon jälleenrakentamiseen.

Päivän esitelmät ja niiden ympärillä käydyt keskustelut osoittivat kuinka erityinen asema Ukrainalla on Venäjän ja Euroopan, idän ja lännen, rajalla. Idän ja lännen välinen jännite ei kuitenkaan jää maan rajoille: käsitellyt tapaukset osoittavat, että se on jo pitkään vaikuttanut myös maan sisällä, toisaalta haastaen kirkkoja ja yksilöitä, toisaalta tarjoten mahdollisuuksia heille, jotka ovat osanneet niitä hyödyntää.

Annika Juurikka

\title{
Mika Perkiömäki Idäntutkimuksen päätoimittajaksi ja Jari Parkkinen toimitussihteeriksi
}

Idäntutkimuksen päätoimittaja vaihtuu vuoden 2022 alusta, kun Mika Perkiömäki aloittaa päätoimittajana Katja Lehtisaaren jälkeen. Lehtisaari on toiminut päätoimittajana vuodesta 2014. Lehden uutena toimitussihteerinä toimii tästä numerosta 4/2021 alkaen Jari Parkkinen, joka seuraa tehtävässä Ira Österbergiä. Österberg on toiminut tässä lehden kannalta oleellisessa roolissa ansiokkaasti vuodesta 2019.

Mika Perkiömäki on tutkijatohtori Helsingin yliopiston Aleksanteri-instituutissa, jossa hän tutkii Venäjän median energiatransitioon ja ilmastonmuutokseen liittyviä esityksiä. Hänen kesällä 2021 Tampereen yliopistossa tarkastettu ekokriittinen väitöskirjansa käsitteli joen merkityksiä 1900-luvun lopun venäläisessä luonnonfilosofisessa proosassa. Hän on työskennellyt kaksi vuotta tutkijana Helsingin yliopiston kielten osastossa aiheenaan varhaisneuvostoliittolaisen pomorikirjallisuuden pohjoisen luonnon esitykset sekä vuoden koordinaattorina Tampereen yliopiston Venäjän ja Kiinan median osaamiskeskuksessa TaRCissa. Tutkija- ja opettajavaihdossa hän on ollut Uralin federaa- tioyliopistossa Jekaterinburgissa. Perkiömäki on Suomen slavistipiirin varapuheenjohtaja, aiempi Kirjallisuudentutkijain Seuran sihteerirahastonhoitaja sekä Venäläisen kirjallisuuden seuran lehden Ajan kohinan toimituskunnan jäsen. Venäjän kielen ja kulttuurin lisäksi hänellä on maisterin tutkinto tietojenkäsittelyopista ja pitkä kokemus työskentelystä it-alalla.

Jari Parkkinen on väitöskirjatutkija Jyväskylän yliopistossa venäjän kielen ja kulttuurin oppiaineessa. Hänellä on maisterintutkinto musiikkitieteen oppiaineesta, ja väitöskirjassaan hän tutkii Neuvostoliiton musiikkipolitiikan muotoutumista ja musiikin käsitteellistämistä vuosina 1917-1934 käsitehistoriallisesta näkökulmasta. Maisteriopintojensa aikana Parkkinen työskenteli harjoittelijana Pohjoismaiden ministerineuvostossa Arkangelissa sekä Aleksanteriinstituutin VIExpert-koulutusohjelmassa, minkä jälkeen häntä ovat työllistäneet väitöskirjan lisäksi konferenssien ja muiden tapahtumien järjestäminen. Parkkinen on ollut Suomen Slavistipiirin hallituksen jäsen vuodesta 2017. 